\title{
Human resource practices and affective organisational commitment: A sectoral comparative study
}

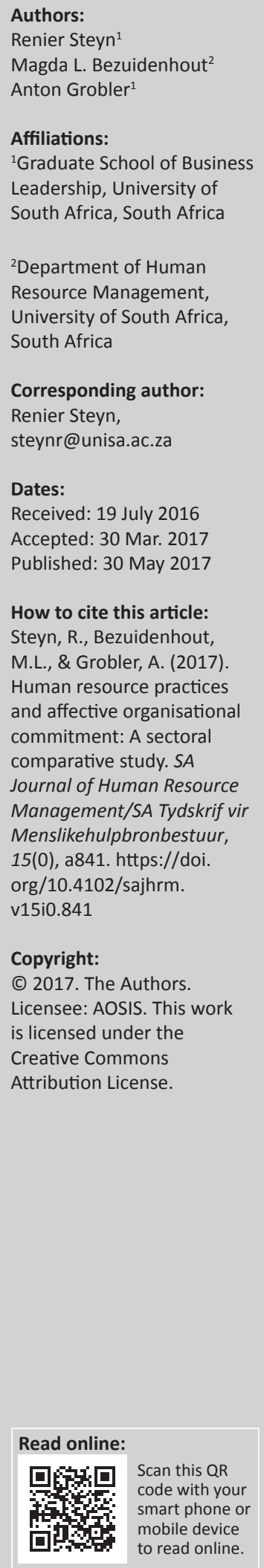

Orientation: Organisational commitment (OC) is often depicted as a desirable employee attitude and relates to organisational performance. Little research has been carried out on the (Human Resource) HR practices-OC relationship within the South African context, and specifically with regard to this relationship across various sectors.

Research purpose: The purpose of this contribution is to specify the HR practices-OC relationship, within South Africa, and specifically across various sectors.

Motivation for the study: It addresses the important matter of OC, a necessary requirement for sustaining organisations, through effective delivery of HR practices.

Research design, approach and method: This study is based on a cross-sectional survey design, collecting primary data on HR practices and OC from South African employees in public and private sector organisations, as well as state-owned entities.

Main findings: Minimal practically significant mean scored differences were detected among HR practices delivered per sector. Furthermore, a positive link between effective HR practices and OC was found within each of the three sectors, but this relationship was sector-specific.

Practical implications: The findings of this study offer a new, contextualised perspective on the HR practices-OC relationship. The data gathered could assist practitioners in reshaping HR policies - and particularly practices - to suit their specific sector.

Contribution and value add: The findings of this study are expected to offer valuable insight into the deferential management along sector lines. They also reiterate the importance of localised research and caution practitioners not to transfer research findings to local settings without a thorough investigation of local research.

\section{Introduction}

Human resource (HR) practices denote the organisational activities aimed at managing the pool of HRs and ensuring that these resources are directed towards the achievement of organisational goals (Chew, 2004; Juhdi, Pa'wan, Hansaram \& Othman, 2011; Rees \& Smith, 2014), including creating a competitive advantage (Şendoğdu, Kocabacak \& Güven, 2013; Zeeshan \& Sabir, 2014). HR practices traditionally play an important role in influencing employee attitudes and behaviour (Nivethitha, Dyaram \& Kamalanabhan, 2014). Coetzee, Mitonga-Monga and Swart (2014) emphasise this dual function of HR practices and state that HR practices represent the management processes and systems that are generally aimed at improving an organisation's performance and efficiency, as well as their employees' attitudes and behaviours. Momemi, Marjani and Saadat (2012) suggest that, particularly in the 21st century, HR practitioners recognise the importance of HR practices and their impact on employee performance, job satisfaction, commitment and retention. Bal, Bozkurt and Ertemsir (2014) specifically state that organisational commitment (OC) as an employee attitude is affected by the delivery of HR practices. Despite the empirical link between HR practices and OC being widely accepted by theorists, the specifics of how they are connected are still weakly grounded, according to Blakenstein (2014).

In this study, the focus will be on the HR practices-OC link. Although Bal et al. (2014) state that well-designed HR practices will increase the commitment of employees and help them to achieve the goals of the organisation, and although Swart (2009) posits that it can be assumed that employees who perceive that their organisation invests in sound HR practices that address their needs will be psychologically and emotionally committed to the organisation, most findings are based mainly on single-firm or organisational studies (Zaitouni, Sawalha \& El, 2011) and have been conducted in the Western world (Hemdi, 2009; Meyer \& Allen, 1997; Nasurdin, Hemdi \& Guat, 2008). 
This article brings to the fore an additional element of the HR practices-OC link discussion, namely the context of the organisation. While an HR delivery model describes how those services are provided (Armstrong, 2012), each HR department is subject to different forces, requiring unique approaches to HR service delivery (Swift, 2012). Kumar and Mishra (2011), for example, found that public and private sector organisations differ significantly with regard to HR practices. A major task is thus to identifying appropriate strategies for different contexts (Aycan, Al-Hamadi, Davis \& Budhwar, 2007). The need exists to test the assumptions and underpinnings of the unitarist approach ('HR best practise' approach), which, according to Marchington and Grugulis (2000), has resulted in the empirically untested assertions that HR practices have a universal effect, irrespective of organisational or industrial context.

\section{Research objectives}

Human resource practitioners may be tempted to think that all HR practices are similarly delivered, similarly valued and similarly effective in all organisational settings, implying sector and industry equivalence. In this research, this hypothesis is tested, focusing on (1) assessing whether there are differences in the mean scores on effective or satisfactory HR delivery in three sectors, and (2) determining whether the relationship between HR practices and OC is similar in each of the three sectors. The last-mentioned refers to the possible effectiveness of HR practices in soliciting desired attitudes, in this case OC.

\section{Literature review}

Human resource services are not delivered in a contextual vacuum. Delery and Doty (1996), as well as Hemdi (2009), conceptualised HR practices as a set of internally consistent policies and services, designed and implemented to ensure that a company's human capital contributes to the achievement of its business objectives. These services are thus not fixed and differ from one organisation to another (Tiwari \& Saxena, 2012). The universalistic perspective, based on the pioneering work of Pfeffer $(1994,1995,1998)$, suggesting that organisational performance depends on common HR practices, regardless of the industry or strategy pursued, seems outdated. Rather, the contingency perspective on HR practices, emphasising the external context in which they are applied (Guest, 1997), and where HR practices are informed by strategy and organisational goals (Aryee \& Budhwar, 2008; Jackson, Schuler \& Rivero, 1989; Porter, 1985), seems appropriate. Given the focus on different economic sectors, the configurational perspective on HR practices may also be more appropriate than the universalistic perspective. The configurational perspective on HR practices mentioned above reflects the notion that distinctive bundles or patterns of HR practices will result in superior organisational performance (Delery \& Doty, 1996; Guest, 1997). In this regard Guest (1997, p. 271) refers to 'patterns of HR practices that are horizontally integrated'.

The manner in which HR practices are presented may also influence the outcomes associated therewith. Rees and
Smith (2014) differentiate between HR practices which are transactional and transformational. Transactional activities focus on supporting administrative needs within organisations, for example record-keeping and day-to-day maintenance, including recruitment, induction, performance management, development system, career development, the separation system and communicating organisational values to the employees (Pareek, 2007). Transformational HR practices, on the other hand, focus on supporting the more macro- or organisational-wide needs. These activities act as change agents for line managers and include HR practices which meet the company's strategic needs (Wright, McMahan, Gerhart \& Snell, 1997).

When considering the goals of public and private sector organisations, it may be argued that the HR practices could differ based on the economic sector. Harel and Tzafrir (2001), for example, found that public sector management emphasised those HR domains that deal with employee selection and grievance procedures because of the sector's high level of unionisation. They also found that private sector management, on the other hand, emphasised employee growth and pay for performance. Also focusing on the types of services delivered, Kumar and Mishra (2011) found that public sector and private sector organisations differ significantly regarding certain $\mathrm{HR}$ dimensions, such as strategic HR; HR planning, training and development; safety and industrial relations. However, these authors found no difference regarding recruitment between the two sectors.

The research of Harel and Tzafrir (2001), as well as that of Kumar and Mishra (2011), thus reflects elements of the contingency perspective and configurational perspective of HR, as well as sector-based differences in transactional and transformational approaches to HR service delivery. Veloso, Tzafrir and Enosh (2015), affirming these differences, report that, in public organisations more than in private organisations, the nature of $\mathrm{HR}$ is perceived as mainly operational and administrative, and as ignoring the diversity of HR practices and the strategic role it can play in the organisation. Vanhala and Stavrou (2013) report that HR is more advanced in private companies than in public sector companies. The aforementioned lack of advancement may be a function of the sector, as Brown (2004) reports that public sector HR is bureaucratic and resistant to change.

Organisational commitment emerged in the 1970s and 1980s (see Mowday, Porter \& Steers, 1982) as a key factor of the relationship between the individual and the organisations (Lamba \& Choudhary, 2013), and has been conceptualised in many different ways (Ghanzanfar, Chuanmin, Siddique \& Bashir, 2012). Early on, Mowday et al. (1982) suggest that individuals who score high on OC tend to have: (1) a strong belief in the organisation's goals and values, (2) a willingness to devote considerable effort in support of the organisation and (3) a keen desire to maintain membership in the organisation. Meyer and Allen (1997) define OC as the feeling of dedication to one's employer, willingness to work hard for 
that employer and the intent to remain with that organisation. Meyer and Allen (1991) suggest a three-component model of OC, namely affective, normative and continuance commitment. The focus of this study is on affective organisational commitment (AOC), as Lamba and Choudhary (2013) argue that AOC is more important to organisational performance than continuance or normative commitment. AOC refers to employees' commitment through emotional attachment to the organisation and a belief in the organisation's values. Committed employees identify with the goals of the organisation and want to be part thereof (Ezirim, Nwibere \& Emecheta, 2012). Employees therefore commit to the organisation because they 'want to' (Lamba \& Choudhary, 2013). AOC is thus the individual employee's psychological attachment to the organisation (Lamba \& Choudhary, 2013).

Kuo (2013) describes OC as an efficient and extremely powerful mechanism for connecting employees and the organisation. Employees who are committed to their organisations could be more willing to participate in 'extrarole' activities, such as being innovative. This is likely to guarantee organisations' competitiveness in the market (Van Dyk \& Coetzee, 2012). Other benefits include improved employee performance and reduced employee turnover (Bal et al., 2014; Yew, 2013). It is important to retain the correct employees, as to make the most of their potential (Ahmad \& Schroeder, 2003). As such, organisations are becoming gradually more interested in the promotion of commitment among employees (Lew, 2011).

The need to keep the workforce committed, and to gain a competitive edge through attracting quality staff, has led to a surge in the research studies trying to look into HR practices and OC relationships (Ghanzanfar et al., 2012). Blakenstein (2014) even suggests that the underlying goal of HR practices is to increase employee commitment. Imran and Ahmed (2012), for example, demonstrated in their research that compensation, perceived organisational support, work-life polices, training and development, career opportunities, empowerment, organisational climate and communication have a direct and positive impact on OC. Further, Zaitouni et al. (2011) found that HR practices that include competence development, fair rewards and information sharing were positively and significantly related to OC. Several other scholars have also examined the relationship between HR practices and OC. A summary of some of these is presented in Table 1.

Kehoe and Wright (2013) and Marescaux, De Winne and Sels (2013) have also studied the link between HR practices and OC but have come up with differing results. At an organisational level, Shahnawaz and Juyal (2006) found that HR practices significantly differ across two organisations and that different HR practices significantly predicted OC in the two organisations. Lamba and Choudhary (2013) investigated the impact of HR practices on the OC of employees in two industries and report sector-specific results. Blakenstein
TABLE 1: Previous research between human resource practices and organisational commitment.

\begin{tabular}{ll}
\hline HR practices linked with OC & Authors \\
\hline $\begin{array}{l}\text { Career development and } \\
\text { planning }\end{array}$ & $\begin{array}{l}\text { Caldwell, Chatman and O'Reilly (1990); Palmer } \\
\text { (2006); Wayne, Shore and Linden (1997) }\end{array}$ \\
$\begin{array}{l}\text { Training and development } \\
\text { Coetzee, Mitonga-Monga and Swart (2014); Palmer } \\
\text { (2006) }\end{array}$ \\
$\begin{array}{l}\text { Recruitment and selection } \\
\text { process }\end{array}$ & Caldwell et al. (1990); Palmer (2006) \\
Performance management & $\begin{array}{l}\text { Ahmed, Mohammad and Islam (2013); Brown, Hyatt } \\
\text { and Benson (2010); Dusterhoff, Cunningham and } \\
\text { Macgregor (2014); Hemdi (2009); Kuvaas (2011); } \\
\text { Mustapha and Daud (2012); Salleh, Amin, Muda and } \\
\text { Halim (2013); Selvarajan and Cloninger (2012) }\end{array}$ \\
& $\begin{array}{l}\text { Coetzee et al. (2014); Caldwell et al. (1990); Kuvaas } \\
\text { (2006); Şendoğdu et al. (2013) }\end{array}$ \\
Remuneration & Coetzee et al. (2014) \\
HR policies & $\begin{array}{l}\text { Allen and Meyer (1990); Bal et al. (2014); Bawa and } \\
\text { Jantan (2005); Chughtai (2013); Jeet and }\end{array}$ \\
HR practices in general & $\begin{array}{l}\text { Sayeeduzzafar (2014); Meyer and Allen (1991, 1997); } \\
\text { Meyer and Smith (2000); Momemi et al. (2012); } \\
\text { Şendoğdu et al. (2013); Steyn (2012); Van Dyk and } \\
\text { Coetzee (2012); Van Straaten-Theron and Dodd } \\
\text { (2011); Zaitouni (2013); Zeeshan and Sabir (2014) }\end{array}$ \\
\hline HR, human resource; OC, organisational commitment.
\end{tabular}

(2014) reported pessimistically that the HR practices-OC link has been left undetermined.

\section{Research design \\ Research approach}

The research design was a cross-sectional survey design, focusing on collecting quantitative data. This design is well suited to studies focusing on the relationship between variables, but not adequate to determine causality (Bryman, 2012). Primary data were collected from South African employees in public and private sector organisations, as well as in in state-owned entities (SOEs). Access to organisations was facilitated by 52 master's degree students. The study was therefore carried out on an opportunity sample of organisations (Rosnow \& Rosenthal, 2008), as it focused only on organisations accessible by students. Once students had gained permission to conduct the study, simple random sampling was performed in each organisation $(N=60)$. Those selected for participation were informed about the scope of the study, as well as all ethical matters in this regard. Only those who volunteered to participate in the study did so, and only after signing an informed consent form. Hereafter, data collection followed. Several instruments, including one on $\mathrm{HR}$ practices and one on OC, were administered. Once the data had been collected, it was coded and the statistical analysis performed.

\section{Data collection methods}

Two instruments were used for collecting data in this study, namely the Human Resource Practices Scale (HRPS) developed by Nyawose (2009) and the Organisational Commitment Scale (OCS) (Allen \& Meyer, 1990).

\section{Human Resource Practices Scale}

The original HRPS (Nyawose, 2009) consisted of 27 items, assessing nine HR practices, with three questions per practice. Nyawose (2009) reports internal consistencies, varying from 
0.74 to 0.93 for these scales. Steyn (2012), using a shorter version of the scale, reports internal consistencies, varying between 0.74 and 0.88 . With regard to validity, Steyn (2012) found that HR practices correlated in an expected manner with aspects such as job satisfaction (positively) and intention to quit (negatively). Only seven HR practices were assessed in this study, namely training and development (T\&D), compensation and rewards (Rem), performance management (PM), supervisor support (SS), staffing (Sta), diversity management (Div) and communication and information sharing (Com).

The following is a typical item, taken from the training and development scale, and reads as follows: 'My company is committed to the training and development needs of its employees'. Respondents were requested to assess the organisation in which they were employed on a five-point scale, ranging from one (1 - disagree strongly) to five (5 agree strongly). For each individual HR practice, the minimum score would be three (3) and the maximum 15. A high score would suggest that the respondent was satisfied with that particular HR practice, while a low score would indicate the opposite. A total score for HR practices, adding the scores of the seven subscales, were also calculated. The range for this score was 21-105. This score was interpreted as indicative of satisfaction with the HR function as a whole.

\section{Organisational Commitment Scale}

The OCS of Allen and Meyer (1990) can generally be used to assess affective, continuance and normative commitment. The scale consists of 24 questions, with 8 questions each on affective, continuance and normative commitment. Even though different conceptualisations of OC have been used in the literature, perhaps the most important with regard to HR practices is the concept of AOC (Lamba \& Choudhary, 2013; Wright \& Kehoe, 2007). Only the eight questions comprising the affective commitment part of the instrument were used. It is common practice to interpret the sections of the test separately (see, for example, Steyn, 2012). Allen and Meyer (1990) report an internal consistency coefficient of 0.86 for the affective commitment section, and Steyn (2012) reports a Cronbach's alpha coefficient for the eight items of 0.82. Allen and Meyer (1990) report evidence of construct validity, although there are some overlaps between affective and normative commitment. They also report that the 'relationship between commitment measures ... and the antecedent variables ... was, for the most part, consistent with prediction' (Allen \& Meyer, 1990, p. 13). This points to convergent and discriminant validity. Steyn (2012) reported correlation coefficients of around 0.30 between OC and the different HR practices.

The first item of the affective commitment part of the scale reads as follows: 'I would be very happy to spend the rest of my career with this organisation'. Respondents were requested to indicate their views on this statement on a scale ranging from 1 (strongly disagree) to 7 (strongly agree). The minimum score was 8 and the maximum 56 . A high score on the scale would be indicative of high levels of commitment and low scores would be indicative of low commitment.

\section{Statistical analysis}

The statistical analysis was performed by using the Statistical Package for the Social Sciences (SPSS version 23). Firstly, statistics about the demographics of the respondents were calculated. Next, central statistics were calculated per sector, specifically the mean score and the standard deviation for each measure.

In order to determine the presence of differences in mean score across the sectors, one-way analysis of variance (ANOVA) was conducted. When the overall ANOVA showed significant differences between groups $(p<0.001)$, the Scheffé post hoc test was used to determine which pairs of groups differed significantly. The effect size of the differences in means between the groups was then determined. The guidelines of Pallant (2010) were used, where $r$ values of 0.30 , 0.50 and 0.80 represent small, medium and large effect sizes, as per calculated Cohen's $d$ values.

Correlations between the independent variables (HR practices) and dependent variable (AOC) were calculated by means of Pearson's product moment correlations. Statistically significant correlations $(p<0.001)$ with values larger than 0.20 were interpreted as indicative of a practically significant correlation. To assess if the significant correlations differed from each other, $z$-observed values were calculated, following a Fisher $r$-to- $z$ transformation. Should the $z$-observed value be greater than 1.96 or smaller than -1.96 , the difference in the correlations would be deemed as statistically significant.

Linear regression analysis was used to determine the amount of variance explained by each of the HR practices in OC. In this case, statistically significant $(p<0.001)$ beta values were interpreted as being indicative of a unique and significant contribution to the dependent variable.

\section{Findings Demographics of the participants}

The participants in this study were employees from different South African companies within the private and public sectors, as well as SOEs. The total number of participants was 3180 employees, representative of 52 companies. The private sector was the largest group, being 1944 (61\% of the total), followed by the public sector with $719( \pm 23 \%)$, followed by the SOEs with 480 , representing $16 \%$ of the total sample.

In total, $57.1 \%$ reported that they were male, compared to $42.5 \%$ reporting that they were female (missing data $=0.4 \%$ ). As far as race is concerned, 8.3\% marked Asian, 58.4\% black, $8.4 \%$ mixed race and $24.6 \%$ white (missing data $=0.3 \%$ ). Their ages ranged between 20 and 72, with an average of 37.80 (standard deviation $=9.11$ ). As far as tenure at their present company is concerned, this varied between 1 month and 42 years, with an average of 8.39 (standard deviation $=7.47$ ). 


\section{Means per sector and mean differences}

A preliminary analysis was performed to ensure that no violation of the assumptions of normality was made. Following satisfactory results, means were calculated. The descriptive statistics, Cronbach's alpha, as well as the results on the ANOVA, are reported in Table 2. From Table 2 (in column 5), it can be seen that the Cronbach alpha coefficient $(\alpha)$, representing the proportional variance error and the internal consistency of the instrument, was acceptable, given the 0.70 or higher mark set by Clark and Watson (1995) and Nunnally and Bernstein (1994). The lowest $\alpha$ value was 0.69 . This permitted further calculations to be performed.

From Table 2 (in column 3), it can be observed that several variations in the mean scores occurred across sectors. The statistical significance of these variations is reported in column 10. Only three individual HR practices (T\&D; Div; Comm) differed significantly on mean scores across sectors, and also the mean aggregate HR practices score (TOT) and the OC scores.

In order to determine between which groups the mean score differences occurred, the Scheffé post hoc test was performed subsequent to the ANOVA. The significant differences between the sectors are reported in Table 3.

From Table 3, we can observe that the only statistical difference between mean scores, which was also practically significant, occurred at the SOEs and public sector on T\&D. Here, the mean difference was 1.09, with a Cohen $d$ value of 0.37 .

\section{Relationship between human resource practices and organisational commitment, per sector}

Pearson product moment correlations were used to determine the relationship between the independent variables (the

TABLE 3: Scheffé post hoc test: Between sectors mean score differences (practically significant differences are underlined).

\begin{tabular}{llll}
\hline Factor & \multicolumn{3}{c}{ Sector comparisons } \\
\cline { 2 - 4 } & Private/public & Private/SOEs & SOEs/public \\
\hline T\&D & $\begin{array}{l}\text { 0.64* (mean } \\
\text { difference) }\end{array}$ & $\begin{array}{l}-0.45^{*} \text { (mean } \\
\text { difference) }\end{array}$ & $1.09 *$ (mean difference) \\
& 0.13 (s.e.) & 0.15 (s.e.) & 0.17 (s.e.) \\
& 0.21 (effect size [d]) & 0.16 (effect size [d]) & 0.37 (effect size [d]) \\
Rem & $\mathrm{n} / \mathrm{s}$ & $\mathrm{n} / \mathrm{s}$ & $\mathrm{n} / \mathrm{s}$ \\
PM & $\mathrm{n} / \mathrm{s}$ & $\mathrm{n} / \mathrm{s}$ & $\mathrm{n} / \mathrm{s}$ \\
SS & $\mathrm{n} / \mathrm{s}$ & $\mathrm{n} / \mathrm{s}$ & $\mathrm{n} / \mathrm{s}$ \\
Sta & $\mathrm{n} / \mathrm{s}$ & $\mathrm{n} / \mathrm{s}$ & $\mathrm{n} / \mathrm{s}$ \\
Div & $0.43^{*}$ (mean & $\mathrm{n} / \mathrm{s}$ & $0.60 *$ (mean difference) \\
& difference) & & \\
& 0.12 (s.e.) & - & 0.16 (s.e.) \\
& 0.16 (effect size [d]) & - & 0.22 (effect size [d]) \\
Com & $0.92 *$ (mean & $0.50 *$ (mean difference) & $\mathrm{n} / \mathrm{s}$ \\
& difference) & & \\
& 0.13 (s.e.) & 0.15 (s.e.) & - \\
& 0.29 (effect size [d]) & 0.18 (effect size [d]) & - \\
TOT & $2.58 *$ (mean difference) & $\mathrm{n} / \mathrm{s}$ & $2.42 *$ (mean difference) \\
& 0.66 (s.e.) & - & 0.90 (s.e.) \\
& 0.17 (effect size [d]) & - & 0.16 (effect size [d]) \\
OC & $\mathrm{n} / \mathrm{s}$ & $-2.22 *$ (mean difference) & $1.97 *$ (mean difference) \\
& - & 0.50 (s.e.) & 0.58 (s.e.) \\
& - & 0.21 (effect size [d]) & 0.23 (effect size [d]) \\
\hline
\end{tabular}

$\mathrm{n} / \mathrm{s}$, not significant; T\&D, Training and development; Rem, Remuneration; PM, Performance management; SS, Supervisor support; Sta, Staffing; Div, Diversity management; Com, management; SS, Supervisor support; Sta, Staffing; Div, Diversity management; Com,
Communication; TOT, Aggregate of Human Resource Practices Scale (HRPS); OC, organisational commitment; SOE, state-owned entities.

$*, p \leq 0.001$

\begin{tabular}{|c|c|c|c|c|c|c|c|c|c|c|}
\hline Factor & Sector & $N$ & Mean & s.d. & $\alpha$ & Sum of squares & $d f$ & Mean square & $F$ & Sig. \\
\hline \multirow[t]{3}{*}{$T \& D$} & Private & 1981 & 11.43 & 2.97 & 0.78 & 374.05 & 2 & 187.03 & 21.47 & $p \leq 0.001$ \\
\hline & SOES & 480 & 11.88 & 2.49 & 0.81 & & & & & \\
\hline & Public & 719 & 10.79 & 3.18 & 0.86 & & & & & \\
\hline \multirow[t]{3}{*}{ Rem } & Private & 1981 & 9.06 & 3.06 & 0.84 & 24.88 & 2 & 12.44 & 1.28 & $\mathrm{n} / \mathrm{s}$ \\
\hline & SOES & 480 & 8.99 & 3.12 & 0.86 & & & & & \\
\hline & Public & 719 & 8.84 & 3.26 & 0.84 & & & & & \\
\hline \multirow{2}{*}{ PM } & SOES & 480 & 10.70 & 2.92 & 0.78 & & & & & \\
\hline & Public & 719 & 10.41 & 3.08 & 0.78 & & & & & \\
\hline \multirow[t]{3}{*}{ SS } & Private & 1981 & 10.63 & 2.96 & 0.85 & 33.20 & 2 & 16.60 & 1.94 & $\mathrm{n} / \mathrm{s}$ \\
\hline & SOES & 480 & 10.55 & 2.71 & 0.83 & & & & & \\
\hline & Public & 719 & 10.38 & 2.99 & 0.85 & & & & & \\
\hline \multirow[t]{2}{*}{ Sta } & Private & 1981 & 10.04 & 2.67 & 0.74 & 32.73 & 2 & 16.37 & 2.32 & $\mathrm{n} / \mathrm{s}$ \\
\hline & SOES & 480 & 10.09 & 2.58 & 0.71 & & & & & \\
\hline \multirow[t]{3}{*}{ Div } & Private & 1981 & 10.24 & 2.60 & 0.74 & 129.70 & 2 & 64.85 & 9.23 & $p \leq 0.001$ \\
\hline & SOES & 480 & 10.41 & 2.67 & 0.77 & & & & & \\
\hline & Public & 719 & 9.81 & 2.78 & 0.77 & & & & & \\
\hline \multirow[t]{3}{*}{ Com } & Private & 1981 & 10.35 & 2.81 & 0.83 & 473.79 & 2 & 236.90 & 28.20 & $p \leq 0.001$ \\
\hline & SOES & 480 & 9.85 & 2.87 & 0.84 & & & & & \\
\hline & Public & 719 & 9.43 & 3.15 & 0.87 & & & & & \\
\hline \multirow[t]{3}{*}{ TOT } & Private & 1981 & 71.84 & 15.12 & 0.93 & 3619.28 & 2 & 1809.64 & 7.79 & $p \leq 0.001$ \\
\hline & SOES & 480 & 71.70 & 14.00 & 0.92 & & & & & \\
\hline & Public & 719 & 69.27 & 16.35 & 0.94 & & & & & \\
\hline \multirow[t]{3}{*}{ OC } & Private & 1981 & 33.94 & 10.87 & 0.84 & 1930.95 & 2 & 965.48 & 9.89 & $p \leq 0.001$ \\
\hline & SOES & 480 & 36.17 & 8.86 & 0.79 & & & & & \\
\hline & Public & 719 & 34.19 & 8.45 & 0.69 & & & & & \\
\hline
\end{tabular}

ANOVA, analysis of variance; $n / s$, not significant; T\&D, Training and development; Rem, Remuneration; PM, Performance management; SS, Supervisor support; Sta, Staffing; Div, Diversity management; Com, Communication; TOT, Aggregate of Human Resource Practices Scale (HRPS); OC, organisational commitment; SOE, state-owned entities. 
TABLE 4: Correlation between human resource practices and organisational commitment, as well as differences in the correlations.

\begin{tabular}{|c|c|c|c|c|c|c|}
\hline \multirow[t]{2}{*}{ HR practices } & \multirow{2}{*}{ Private sector ${ }_{\mathrm{a}}\left(r_{\mathrm{a}}\right)$} & \multirow{2}{*}{$\operatorname{SOEs}_{b}\left(r_{b}\right)$} & \multirow{2}{*}{ Public sector ${ }_{c}\left(r_{c}\right)$} & \multicolumn{3}{|c|}{ Significance of differences between correlations ( $z$-observed) } \\
\hline & & & & a,b & $a, c$ & b,c \\
\hline$T \& D$ & $0.40^{*}$ & $0.30 *$ & $0.34 *$ & $2.24 \dagger$ & 1.59 & -0.75 \\
\hline Rem & $0.37 *$ & $0.33 *$ & $0.39 *$ & 0.89 & -0.54 & -1.17 \\
\hline PM & $0.39 *$ & $0.25 *$ & $0.33^{*}$ & $3.07 \dagger$ & 1.58 & -1.48 \\
\hline SS & $0.41^{*}$ & 0.14 & $0.28 *$ & $5.78 \dagger$ & $3.39 \dagger$ & $-2.48 \dagger$ \\
\hline Sta & $0.37^{*}$ & $0.30 *$ & $0.31 *$ & 1.55 & 1.56 & -0.19 \\
\hline Div & $0.36^{*}$ & $0.21 *$ & $0.32 *$ & $3.21 \dagger$ & 1.04 & $-2.0 \dagger$ \\
\hline Com & $0.41^{*}$ & $0.27 *$ & $0.37 *$ & $3.11 \dagger$ & 1.08 & -1.89 \\
\hline Total & $0.51^{*}$ & $0.37 *$ & $0.44 *$ & $3.42 \dagger$ & $2.07 \dagger$ & -1.42 \\
\hline
\end{tabular}

T\&D, Training and development; Rem, Remuneration; PM, Performance management; SS, Supervisor support; Sta, Staffing; Div, Diversity management; Com, Communication; TOT, Aggregate of Human Resource Practices Scale (HRPS); HR, human resource; OC, organisational commitment; SOE, state-owned entities.

$\dagger$, Significant differences between correlations $\left(-1.96 \leq z_{\text {obs }} \geq 1.96\right)$.

$*, p \leq 0.001$.

individual HR practices and the aggregate score on the HR practices scale) and OC (as the dependent variable). A preliminary analysis was performed to ensure no violation of the assumptions of normality, linearity and homoscedasticity. Following satisfactory results, correlations were calculated. These coefficients, presented in Table 4, were all positive and statistically significant, with the exception of the correlation between SS and OC for the SOEs $(r=0.14)$.

The correlation between TOT and OC had a large effect $(r=51)$ in the private sector. In all the other cases, the correlations were of a medium effect size. In general, the HR practices individually, as well as collectively (TOT), relate to OC. When considering the TOT scores for the three sectors, it can also be observed that the correlation for the aggregate score for HR practices is the highest for the private sector $(r=0.51)$, followed by the public sector $(r=0.44)$ and the SOEs $(r=0.37)$. These correlations are statistically, as well as practically, significant.

This brings to the fore the matter of significance of the differences between the ways HR practices correlate with OC. The extent to which the correlations differ across sectors was calculated as $z$-observed values. Focusing only on TOT's correlation with OC, the $z$-observed values of 3.42 (private sector-SOEs) and 2.07 (private sector-public sector) indicate that the correlation for the private sector is higher than that of the SOEs, and also that the correlation for the private sector is higher than that of the public sector, but that the correlations of the SOEs and the public sector did not differ significantly. On a subscale level, the way HR practices correlated with OC differed in five instances between the private sector and SOEs, once in the case of private sector and public sector, and twice when comparing SOEs and the public sector. In all five cases, private sector correlations were stronger than SOE correlations. In the one case where the correlations between the private sector and the public sector differed, the correlations were also stronger in the private sector. As far as the differences in correlations between SOEs and the public sector are concerned, the correlations were stronger in the public sector.

Linear regression was next to determine the extent to which all the HR practices combined (excluding the aggregate score on the HRPS) explained the variance in OC, as well as which
TABLE 5: Model summary of regression analysis - Variance explained in organisational commitment by human resource practices.

\begin{tabular}{lccccc}
\hline Sector & $\boldsymbol{R}$ & $\boldsymbol{R}^{\mathbf{2}}$ & Adjusted $\boldsymbol{R}^{\mathbf{2}}$ & s.e. & Sig. \\
\hline Private sector & 0.52 & 0.27 & 0.27 & 9.06 & $p \leq 0.001$ \\
SOE & 0.42 & 0.18 & 0.16 & 8.11 & $p \leq 0.001$ \\
Public sector & 0.45 & 0.20 & 0.19 & 7.60 & $p \leq 0.001$ \\
Combined & 0.48 & 0.23 & 0.23 & 8.72 & $p \leq 0.001$ \\
\hline
\end{tabular}

Predictors: (constant), all HR practices.

Dependent variable: OC.

$\mathrm{HR}$, human resource; OC, organisational commitment.

TABLE 6: Unique contributions of predictors to variance in organisational commitment (only standardised coefficients are presented).

\begin{tabular}{|c|c|c|c|c|c|c|}
\hline \multirow[t]{2}{*}{ HR practice } & \multicolumn{2}{|c|}{$\begin{array}{l}\text { Private sector: } \\
\text { standardised } \\
\text { coefficient }\end{array}$} & \multicolumn{2}{|c|}{$\begin{array}{l}\text { SOE: standardised } \\
\text { coefficient }\end{array}$} & \multicolumn{2}{|c|}{$\begin{array}{l}\text { Public sector: } \\
\text { standardised } \\
\text { coefficient }\end{array}$} \\
\hline & $\beta$ & $t$ & $\beta$ & $t$ & $\beta$ & $t$ \\
\hline Constant & - & 7.49 & - & 8.62 & - & 14.70 \\
\hline$T \& D$ & $0.16^{*}$ & 6.41 & $0.21 *$ & 4.37 & 0.12 & 2.79 \\
\hline Rem & 0.08 & 2.98 & $0.18 *$ & 3.39 & $0.20 *$ & 3.93 \\
\hline PM & 0.06 & 2.28 & 0.02 & 0.033 & -0.01 & -0.02 \\
\hline SS & $0.16^{*}$ & 6.53 & -0.05 & -1.00 & 0.04 & 0.83 \\
\hline Sta & 0.07 & 2.56 & 0.15 & 2.66 & 0.03 & 0.64 \\
\hline Div & 0.04 & 1.70 & -0.05 & -0.82 & 0.03 & 0.55 \\
\hline Com & $0.11 *$ & 4.06 & 0.04 & 0.73 & 0.15 & 2.90 \\
\hline
\end{tabular}

T\&D, training and development; Rem, remuneration; PM, performance management; SS, supervisor support; Sta, staffing; Div, diversity management; Com, communication; SOE, state-owned entities.

$*, p \leq 0.001$

individual HR practices contributed uniquely to the variance in OC. The results are reported in Tables 5 and 6.

Consistent with the results of the correlation coefficients reported in Table 4, the total variance explained by the seven HR practices (this time, each contributed with its unique weighting), is highest for the private sector ( $27 \%$ variance explained), compared to the public sector and SOEs with $19 \%$ and $16 \%$ of the variance explained respectively (all $p \leq 0.001$ ). To isolate the unique contribution of each of the HR practices to variance in $\mathrm{OC}$, the $\beta$ values of the abovementioned regression shown in Table 6 are relevant.

The uniqueness of the three sectors under investigation is apparent from these results. For the private sector, T\&D and SS each have the highest contribution $(\beta=0.16 ; p \leq 0.001)$, followed by Com $(\beta=0.11 ; p \leq 0.001)$. For the SOEs, T\&D $(\beta=0.21 ; p \leq 0.001)$ and Rem $(\beta=0.18 ; p \leq 0.001)$ contributed uniquely and significantly to OC. Lastly, in the public sector, 
only $\operatorname{Rem}(\beta=0.20 ; p \leq 0.001)$ contributed uniquely and significantly to the variance explained in OC.

\section{Discussion}

The research answers the call not to address and assess organisational issues in mainly a single-firm, organisationwide or western world context. In total, 52 organisations, which could be divided into three sectors and which involved 3180 South African employees, were examined. This constitutes a relatively large study. However, it is not a flawless sample in all respects, as the selection of organisations was opportunity based. Note that sampling within organisations was random.

The first objective of the study was to assess whether there are differences in the mean scores on effective/satisfactory HR delivery in three sectors. Statistically significant differences in mean scores were found, $4 / 7$ times for the private sector/ public sector comparisons, and 2/7 times for both the private sector or SOEs and SOEs or public sector comparisons. Only one of the comparisons yielded a practically significant value. Thus, in only $1 / 21$ comparisons on mean differences, this was practically significant. It was, consequently, not possible to replicate the findings of Lamba and Choudhary (2013), who found differences across sectors on effective or satisfactory HR delivery. The universalistic perspective (Pfeffer, 1994, 1995, 1998) of HR practices, suggesting that organisational performance depends on common HR practices, regardless of the industry or strategy pursued, seems to be supported by the data. Focusing on the mean differences (not) detected in this study, neither the contingency perspective nor the configurational perspective on $\mathrm{HR}$ practices could be supported. HR practitioners would therefore not be wrong to assume that all HR practices are similarly delivered and valued (by employees) across organisational settings.

The second objective of the study was to determine whether the relationship between HR practices and OC is similar in each of the three sectors. Do effective HR practices coincide with higher levels of OC? It was found that there is a link between effective HR practices and OC within each of the three sectors. Given the correlation between the HR practices, total score and $\mathrm{OC}$, the link was the strongest for the private sector, followed by the public sector, and lastly the SOEs. These scores were practically significant. Considering the correlation of the per HR practice scores with OC scores, all of these reach statistical significance, with 20/21 at a practically significant level. There seems to be a strong correlation between perception on HR practices and OC.

However, the size of these correlations differs per sector. Private sector-SOEs differences in correlations accord 5/7 times and, in all cases, the correlations were higher for the private sector. Private sector-public sector differences occurred only $1 / 7$ times, once again with the correlation being larger for the private sector. Lastly, 2/7 differences occurred when comparing the SOEs with the public sector, with the correlations for the public sector being higher.
The aforementioned suggests that the effects of HR practices on OC is the highest in the private sector, lower in the public sector, and the lowest in SOEs. This may be related to the manner in which HR practices are presented. Should HR services be delivered in a transformational manner in the private sector, as a change agent, and should HR services be delivered in a transactional manner in the public sector, only supporting the administrative needs within organisations (as Brown [2004] and Veloso et al. [2015] imply), some of these differences in correlations could be explained. HR practitioners should take note of these findings, which imply that HR practices have different levels of efficacy and that such efficacy is sector-specific and may be related to the way services are delivered.

Evidence from the regression analysis showed that the total variance explained by the seven HR practices is higher for the private sector $(27 \%)$, compared to the public sector $(19 \%)$ and SOEs (16\%). This finding corresponds to that of Allen and Meyer (1990), Bal et al. (2014), Bawa and Jantan (2005), Chughtai (2013), Jeet and Sayeeduzzafar (2014), Meyer and Allen (1997), Meyer and Smith (2000), Momemi et al. (2012), Şendoğdu et al. (2013), Steyn (2012), Van Dyk and Coetzee (2012), Van Straaten and Dodd (2011) and Zeeshan and Sabir (2014). This may confirm, as Ahmad and Schroeder (2003) optimistically state, that OC acts as a sign that verifies whether the HR practices utilised in an organisation are able to promote psychological links between organisational and employee goals. This link may be present in transformational, rather than in transactional HR practices.

\section{Limitations of the study and directions for future research}

The findings of the present study are not without limitations, and these should be taken into consideration in future studies of this nature. As stated earlier, part of the sampling was performed in an opportunistic manner. Future researchers may benefit from the random sampling of organisations. Another limitation concerns the control variables of economic conditions, government policies and the political system, none of which were included. Nonetheless, they have been demonstrated as important predictors of $\mathrm{HR}$ practices (Aladwan, Bhanugopan \& D’Netto, 2015). The aforementioned moderators will most likely affect public sector organisations as well as SOEs more than private sector organisations, thus limiting their ability to act in a transformational manner. Future research could include those as well as other moderating variables, which might have some effect on the relationship between HR practices and OC. Lastly, the research may suggest a causal relationship between HR practices and OC, which cannot be determined by applying this design. To investigate this link, quasi-experimental or longitudinal studies are suggested to future researchers.

\section{Conclusion}

Employees' satisfaction with the delivery of HR services across sectors may be similar, but the effects thereof differ. If applied in a seemingly transformational environment, the 
effects are more pronounced than when delivered in a transactional environment.

Human resource practitioners and managers are therefore alerted to the fact that the effectiveness of HR practices may not be a function of the services delivered, but rather whether the services are intended to be transformational or transactional. HR practitioners and managers are thus urged to act in a transformational manner in order to optimise the effects of their actions. Further, by knowing the unique contribution that each of the HR practices makes towards explaining the variance in $\mathrm{OC}$ in the different sectors, $\mathrm{HR}$ practitioners within these organisations can make more informed decisions on what HR practices to offer in order to obtain certain outcomes.

The results of this study contribute to the body of knowledge on HR practices and OC literature by highlighting and providing insights into sector-specific effects among South African employees. The findings of this study offer new contextual perspectives on how HR practices affect $O C$ and could assist in reshaping HR policies and, in particular, HR implementation in South African organisations.

\section{Acknowledgements Competing interests}

The authors declare that they have no financial or personal relationships that may have inappropriately influenced them in writing this article.

\section{Authors' contributions}

R.S. was the project leader. A.G. assisted in collecting the data and data analysis. M.L.B. played a primary role in writing the literature review.

\section{References}

Ahmad, S., \& Schroeder, R.G. (2003). The impact of human resource management services on operational performance: Recognizing country and industry services on operational performance: Recognizing country and industry
differences. Journal of Operations Management, 21, 19-43. https://doi.org/ 10.1016/S0272-6963(02)00056-6

Ahmed, I., Mohammad, S.K., \& Islam, T. (2013). The relationship between perceived fairness in performance appraisal and organisational citizenship behaviour in the banking sector of Pakistan: The mediating role of organisational commitment. International Journal of Management and Innovation, 5(2), 75-88.

Aladwan, K., Bhanugopan, R., \& D'Netto, B. (2015). The effects of human resource management services on employees' organisational commitment. International Journal of Organizational Analysis, 23(3), 472-492. https://doi.org.10.1108/IJOA11-2014-0822

Allen, N.J., \& Meyer, J.P. (1990). The measurement and antecedents of affective, continuance and normative commitment to the organisation. Journal of Occupationa Psychology, 63, 1-18. https://doi.org/10.1111/j.2044-8325.1990.tb00506.x

Armstrong, M. (2012). Armstrong's handbook of human resource management services. (12th edn.). London: Kogan Page

Aryee, S., \& Budhwar, P. (2008). Human resources management and organizational performance. In M.J.R. Butler (Ed.), Strategic human resources: Building a research-based practice (pp. 191-212). London: Charted Institute for Personnel Development.

Aycan, Z., Al-Hamadi, A.B., Davis, A., \& Budhwar, P. (2007). Cultural orientations and preferences for HRM policies and services: The case for Oman. International Journal of Human Resource Management, 18(1), 11-32. https://doi.org/10.1080/ 09585190601068243

Bal, Y., Bozkurt, S., \& Ertemsir, E. (2014, June). Determining the influence of HRM services on increasing organizational commitment: An empirical research from Turkey. Paper presented at the Human Capital without Border: Knowledge and Learning for Quality of Life, Portorož, Slovenia.
Bawa, M.A., \& Jantan, M. (2005). Human resource practices as determinant of employee turnover: An empirical investigation. Asian Academy of Management Journal, 10(2), 69-80.

Blakenstein, H. (2014, November). HR practices to affective commitment: Through active knowledge and skills. Paper presented at the 4th IBA Bachelor Thesis Conference, Enschede, the Netherlands.

Brown, K. (2004). Human resource management in the public sector. Public Management Review, 6(3), 303-309. Retrieved June 20, 2016, from https:// yellowedge.files.wordpress.com/2008/06/brown.pdf

Brown, M., Hyatt, D., \& Benson, J. (2010). Consequences of the performance appraisal experience. Personnel Review, 39(3), 375-396. https://doi.org/10.1108/ 00483481011030557

Bryman, A.D. (2012). Social research methods. (4th edn.). New York: Oxford University Press.

Caldwell, D.F., Chatman, J.A., \& O'Reilly, C.A. (1990). Building organizational commitment: A multifirm study. Journal of Occupational Psychology, 63, 245-261. commitment: A multifirm study. Journal of Occupation
https://doi.org/10.1111/j.2044-8325.1990.tb00525.x

Chew, J.C.L. (2004). The influence of human resource management services on the retention of core employees of Australian organization: An empirical study. Unpublished Doctoral dissertation, Murdoch University, Murdoch.

Chughtai, T.A. (2013). Role of HR practices in turnover intentions with the mediating effect on employee engagements. WSEAS Transactions on Business and Economics, 10(2), 97-103.

Clark, L.A., \& Watson, D. (1995). Constructing validity: Basic issues in objective scale development. Psychological Assessment, 7, 309-319. https://doi.org/10.1037/ 1040-3590.7.3.309

Coetzee, M., Mitonga-Monga, J., \& Swart, B. (2014). Human resource services as predictors of engineering staff's organisational commitment. South African Journal of Human Resource Management, 12(1), Art. \#604, 1-9. https://doi.org/ 10.4102/sajhrm.v12i1.604

Delery, J.E., \& Doty, D. (1996). Modes of theorizing in strategic human resource management: Tests of universalistic, contingency and configurational performance predictions. Academy of Management Journal, 39(4), 802-835. https://doi.org/ $10.2307 / 256713$

Dusterhoff, C., Cunningham, J., \& McGregor, J.N. (2014). The effects of performance rating, leader-member exchange, perceived utility, and organizational justice on performance appraisal satisfaction: Applying a moral judgment perspective. Journal of Business Ethics, 119, 265-273. https://doi.org/10.1007/s10551-0131634-1

Ezirim, C.B., Nwibere, B.M., \& Emecheta, B.C. (2012). The influence of corporate culture on organizational commitment: The Nigerian experience. International Journal Business \& Public Administration, 9, 155-180.

Ghanzanfar, F., Chuanmin, S., Siddique, M., \& Bashir, M. (2012). Exploring the relationship between human resource management services and organizational commitment: Empirical evidence from the banking sector in China. Information Management and Business Review, 4(9), 502-516.

Guest, D.E. (1997). Human resource management and performance: A review and research agenda. International Human Resources Management, 8, 263-276. https://doi.org/10.1080/095851997341630

Harel, G.H., \& Tzafrir, S.S. (2001). HRM services in the public and private sectors: Differences and similarities. Pubic Administration Quarterly, 25(3), 316-355.

Hemdi, M.A. (2009). Investing hotel employees' organizational commitment: The influence of human resource management services and perceived organizational support. Journal of Tourism, Hospitality \& Culinary Arts, 1, 1-18.

Imran, A., \& Ahmed, M. (2012). Impact of human resource services on organizationa commitment: A study among service sector employees in Pakistan Interdisciplinary Journal of Contemporary Research in Business, 4(2), 81-90.

Jackson, S.E., Schuler, R.S., \& Rivero, J.C. (1989). Organizational characteristics as predictor of personnel practises. Personnel Psychology, 42, 727-786. https://doi. org/10.1111/j.1744-6570.1989.tb00674.x

Jeet, V., \& Sayeeduzzafar, Dr. (2014). A study of human resource management practices and organizational commitment in self-financed professional institutions. International Journal of Advance Research in Computer Science and Management Studies, 2(1), 69-73.

Juhdi, N., Pa'wan, F., Hansaram, R.M., \& Othman, N.A. (2011). HR practices, organizational commitment and turnover intention: A study on employees in Klan Valley, Malaysia. Recent Researches in Applied Economics, 30-36.

Kehoe, R.R., \& Wright, P.M. (2013). The impact of high-performance human resource services on employees' attitudes and behaviours. Journal of Management, 39(2), 366-391. https://doi.org/10.1177/0149206310365901

Kumar, Y., \& Mishra, A.K. (2011). Measuring human resource functions: A comparison of public sector and private sector organisations. Management Insight, 8(1), 1-7.

Kuo, Y.K. (2013). Organisational commitment in an intense competition environment. Industrial Management \& Data System, 113(1), 39-59. https://doi.org/10.1108/ 02635571311289656

Kuvaas, B. (2006). Work performance, affective commitment, and work motivation: The roles of pay administration and pay level. Journal of Organisational Behavior, 27(3), 365-385. https://doi.org/10.1002/job.377

Kuvaas, B. (2011). The interactive role of performance appraisal reactions and regular feedback. Journal of Managerial Psychology, 26(2), 123-137. https://doi.org/ 10.1108/02683941111102164

Lamba, S., \& Choudhary, N. (2013). Impact of HRM services on organizational commitment of employees. International Journal of Advancements in Research \& Technology, 2(4), 407-423. 
Lew, T.Y. (2011). Affective organizational commitment and turnover intention of academics in Malaysia. In Proceedings of the International Conference on Business and Economics Research, 26 November 2011, Kuala Lumpur, Malaysia.

Marchington, M., \& Grugulis, I. (2000). 'Best practice' human resource management: Perfect opportunity or dangerous illusion? The International Journal of Human Resource Management, 11(6), 1104-1124. https://doi.org/10.1080/ 09585190050177184

Marescaux, E., De Winne, S., \& Sels, L. (2013). HR practices and HRM outcomes: The role of basic need satisfaction. Personnel Review, 42(21), 4-27.

Meyer, J.P., \& Allen, N.J. (1991). A three-component conceptualization of organizational commitment. Human Resource Management Review, 1(1), 61-89. Retrieved July 18 2016, from http://www.sciencedirect.com/science/article/pii/105348229190011Z

Meyer, J.P., \& Allen, N.J. (1997). Commitment in the workplace: Theory, research, and application. Thousand Oaks, CA: Sage.

Meyer, J.P., \& Smith, C.A. (2000). HRM services and organizational commitment: Test of mediation model. Canadian Journal of Administration Science, 17(4), 319-331. https://doi.org/10.1111/j.1936-4490.2000.tb00231.x

Momemi, M., Marjani, A.B., \& Saadat, V. (2012). The relationship between organisational culture and organisational commitment in staff of general prosecutors of Tehran. International Journal of Business \& Social Sciences, 3(13) prosecutors $217-221$.

Mowday, R.T., Porter, L.W., \& Steers, R.M. (1982). The measurement of organizational commitment. Journal of Vocational Behavior, 14, 224-247. https://doi.org/ 10.1016/0001-8791(79)90072-1

Mustapha, M., \& Daud, N. (2012). Perceived performance appraisal effectiveness and turnover intention of knowledge workers. Interdisciplinary Journal of Contemporary Research in Business, 3(19), 157-165.

Nasurdin, A.M., Hemdi, M.A., \& Guat, L.P. (2008). Does perceived organizational support mediate the relationship between human resource management services and organizational commitment? Asian Academy of Management Journal, 13(1) 15-36.

Nivethitha, S., Dyaram, L., \& Kamalanabhan, T.J. (2014). Relationship between human resource services and employee turnover intention in hospitality industry. Global Journal of Management and Business Research: An Administration and Management, 14(1), 35-42.

Nunnally, J.C., \& Bernstein, I.H. (1994). Psychometric theory. (3rd edn.). New York: McGraw-Hill.

Nyawose, M. (2009). The relationship between human resources management services, organisational commitment and turnover intentions amongst engineering professionals. Unpublished Master's thesis, University of South Africa, Pretoria, South Africa.

Pallant, J. (2010). SPSS survival manual: A step by step guide to data analysis using SPSS for Windows. (4th edn.). Berkshire: Open University Press.

Palmer, L. (2006). The impact of human resource management services on employees Commitment in the Banking Sector in Kingston. Unpublished PhD thesis, Nova Southeastern University, ProQuest, Jamaica.

Pareek, U. (2007). Transformational HRM: A brief outline. Retrieved June 12, 2016 from http://udaipareek.blogspot.co.za/2007/03/transformational-hr.html

Pfeffer, J. (1994). Competitive advantage through people. Boston, MA: Harvard Business School Press.

Pfeffer, J. (1995). Producing sustainable competitive advantage through effective management of people. Academy of Management Executive, 9, 55-69. https:// doi.org/10.5465/ame.1995.9503133495

Pfeffer, J. (1998). The human equation: Building profits by putting people first. Boston, MA: Harvard Business School Press.

Porter, M. (1985). Competitive advantage: Creating and sustaining superior performance. New York: Free Press.

Rees, G., \& Smith, P.E. (2014). Strategic human resource management: An international perspective. (1st edn.). London: Sage Publications.

Rosnow, R.L., \& Rosenthal, R. (2008). Beginning behavioural research: A conceptual primer. (6th edn.). Upper Saddle River, NJ: Pearson/Prentice Hall.
Salleh, M., Amin, A., Muda, S., \& Halim, M.A.S.A. (2013). Fairness of performance appraisal and organisational commitment. Asian Social Science, 9(2), 121-128. https://doi.org/10.5539/ass.v9n2p121

Selvarajan, T., \& Cloninger, P.A. (2012). Can performance appraisals motivate employees to improve performance? A Mexican study. The International Journal of Human Resource Management, 23, 3063-3084. https://doi.org/10.1080/0958 5192.2011.637069

Şendoğdu, A.A., Kocabacak, A., \& Gúven, S. (2013). The relationship between human resource management services and organizational commitment: A field study. Procedia: Social and Behavioral Sciences, 99, 818-827. https://doi.org/10.1016/j. sbspro.2013.10.553

Shahnawaz, M.G., \& Juyal, R.C. (2006). Human resource management services and organizational commitment in different organizations. Journal of the Indian Academy of Applied Psychology, 32(3), 171-178.

Steyn, R. (2012). Human resource services and employee attitudes: A study of individuals in ten South African companies. Alternation: Interdisciplinary Journal for the Study of the Arts and Humanities in Southern Africa, 5, 167-184.

Swart, B. (2009). Best company services and organisation commitment: An exploratory study of an engineering company. Unpublished MBA dissertation, Graduate School of Business Leadership, University of South Africa, Pretoria, South Africa.

Swift, G. (2012). Human resource service delivery. In S. Taylor \& C. Woodhams (Eds.), Managing people and organisations (pp. 1-22). London: Chartered Institute of Personnel \& Development.

Tiwari, P., \& Saxena, K. (2012). Human resource management services: A comprehensive review. Pakistan Business Review, January, 669-705.

Van Dyk, J., \& Coetzee, M. (2012). Retention factors in relation to organisational commitment in medical and information technology services. South African Journal of Human Resource Management, 10(2), 433-444. https://doi. org/10.4102/sajhrm.v10i2.433

Van Straaten-Theron, A., \& Dodd, N.M. (2011). Organisational commitment in a postmerger situation. South African Journal of Economic and Management Sciences, 14(3), 333-345.

Vanhala, S., \& Stavrou, E. (2013). Human resource management services and the HRM-performance link in public and private sector organizations in three Western societal clusters. Baltic Journal of Management, 8(4), 416-437. https://doi.org/ 10.1108/BJM-12-2012-0115

Veloso, A., Tzafrir, S., \& Enosh, G. (2015). How employees perceive HRM services: Differences between public and private organizations. In C.F. Machado \& J.P Davim (Eds.), Human resource management challenges and changes (pp.19-36). New York: NOVA Publishers.

Wayne, S.J., Shore, L.M., \& Linden, R.C. (1997). Perceived organizational support and leader-member exchange: A social exchange perspective. Academy of Management Journal, 40, 82-111. https://doi.org/10.2307/257021

Wright, P.M., \& Kehoe, R.R. (2007). Human resource services and organizational commitment: A deeper examination. Human Resource Services and Organizationa Commitment, CAHRS WP07-15. Accessed January 26, 2017, from http:// digitalcommons.ilr.cornell.edu/cgi/viewcontent.cgi?article=1473\&context= cahrswp

Wright, P.M., McMahan, G., Gerhart, B., \& Snell, S.A. (1997). Strategic human resource management: Building human capital and organizational capability. Ithaca, NY: Cornell University.

Yew, L.T. (2013, July). The influence of human resources management (HRM) services on organizational commitment and turnover intention of academics in Malaysia: The organizational support perspective. Paper presented at the International Conference of Business and Information, Bali, Indonesia.

Zaitouni, M., Sawalha, N.N., \& El, S.A. (2011). The impact of human resource management services and organizational commitment in the banking sector in Kuwait. International Journal of Business and Management, 6(6), 108-123. https://doi.org/10.5539/ijbm.v6n6p108

Zeeshan, M., \& Sabir, H.M. (2014). The effects of cultural dimensions and HR practices on organizational commitment: An empirically evidence from the telecom sector in Pakistan. European Journal of Business and Management, 16(23), 204-208. 